\title{
First Report of the Co-occurrence of Cylindrospermopsin, Nodularin and Microcystins in the Freshwaters of Lake Victoria, Tanzania
}

\author{
Geofrey J. Mchau ${ }^{1,3}$ (D) Revocatus Machunda ${ }^{1} \cdot$ Martin Kimanya ${ }^{1} \cdot$ Edna Makule $^{1} \cdot$ Yun Yun Gong ${ }^{2}$. \\ Emmanuel Mpolya ${ }^{1} \cdot$ Julie P. Meneely ${ }^{4}$. Christopher T. Elliott ${ }^{4} \cdot$ Brett Greer $^{4}$
}

Received: 8 November 2019 / Revised: 29 May 2020 / Accepted: 11 July 2020 / Published online: 26 July 2020

(c) The Author(s) 2020

\begin{abstract}
There is a global concern regarding the increase of cyanotoxins in freshwater and their potential effects on human health. The existence of multiple toxins in freshwater can result in an increased risk of their bioaccumulation in humans from their ingestion through contaminated drinking water or recreational activities. This study, the first of its kind, was conducted to determine the occurrence of thirteen cyanotoxins namely; microcystins (-LA, -LF, -LR, -LY, -LW, -RR, -YR, -WR, dm MC-RR and dm MC-LR), anatoxin-a, nodularin and cylindrospermopsin in the freshwaters of Lake Victoria in Tanzania. A total of 23 sites were selected for water sampling. Samples were randomly collected from lakeshores $(n=54)$, wells $(n=66)$ and piped water $(n=18)$ in two phases, February (dry season) and December (rainy season) 2018. Samples $(n=138)$ were analysed using liquid chromatography mass spectrometry (UPLC-MS/MS). Cylindrospermopsin was the most abundant cyanotoxin detected in the lakeshores, with eight of the nine collection sites (89\%) reporting cylindrospermopsin in phase I, compared to three out of nine (33\%) in phase II. Microcystin congeners -RR, -LR and -YR were detected in phase I, with microcystins -RR and -LR detected in phase II. MC concentrations ranged from 0.003 to $0.007 \mu \mathrm{g} / \mathrm{L}$ for MC-RR, $0.01-0.013 \mu \mathrm{g} / \mathrm{L}$ for MC-LR and 0.004 to $0.01 \mu \mathrm{g} / \mathrm{L}$ for cylindrospermopsin, with nodularin reported once at a concentration of $0.01 \mu \mathrm{g} / \mathrm{L}$. No cyanotoxins were detected in wells or in treated pipe water samples. The existence of multiple toxins in different collection sites may lead to synergistic effects and increase the toxicological risk to humans. This is the first study to report the presence of cylindrospermopsin and nodularin in the freshwaters of Lake Victoria.
\end{abstract}

Keywords Cylindrospermopsin $\cdot$ Lake Victoria $\cdot$ Nodularin $\cdot$ Microcystin

\section{Introduction}

Cyanobacteria blooming in freshwaters present major ecological and health problems worldwide due to their ability to produce secondary metabolites known as cyanotoxins. Cyanotoxins can be classified into two criteria based either on their mechanism of action, such as their action on

Geofrey J. Mchau

gmchau80@gmail.com

1 Nelson Mandela Africa Institute of Science and Technology, P.O. Box 447, Arusha, Tanzania

2 School of Food Science and Nutrition, University of Leeds, Leeds LS2 9JT, UK

3 Ministry of Health, Community Development, Gender, Elderly and Children, P.O. Box 573, Dodoma, Tanzania

4 Institute for Global Food Security, School of Biological Sciences, Queen's University Belfast, Belfast BT9 5DL, UK terrestrial vertebrates and more so on mammals which can lead to hepatotoxicity, neurotoxicity, and dermatotoxicity, or according to their chemical structure e.g. cyclic peptides, alkaloids or lipopolysaccharides (Carmichael 1992). Of these cyanotoxins, the hepatotoxins including microcystins (MC), such as MC-LR, MC-RR and MC-YR can potentially contaminate water and pose a health risk to humans (Carmichael et al. 2001). MC and nodularin (NOD), another hepatotoxin, share a common characteristic that is the amino acid Adda, which is responsible for these molecules toxicity (Funari and Testai 2008; Greer et al. 2018). Repeated exposures to these freshwater toxins can lead to acute and chronic health problems (Buratti et al. 2017). Based on the threat of MC in drinking water, the World Health Organisation (WHO) proposed a provisional acceptable concentration limit of $1.0 \mu \mathrm{g} / \mathrm{L}$ for MC-LR in drinking water (WHO 2008).

Cyanotoxin-related human health effects vary according to the type of toxin and route of exposure, which include; 
swimming, bathing and ingestion of contaminated water. Several acute effects such as nausea, vomiting, diarrhoea, mouth blisters, irritation of the skin, throat and eyes have been documented (Kibria 2016). Fatalities were reported at a Brazilian renal dialysis unit where some individuals exposed to MC in contaminated water developed hepatic failure and death occurred (Pouria et al. 1998). Moreover, acute cases of microcystin poisoning can lead to human and animal death. Following ingestion, MCs are transported to the liver by organic anion transport proteins (OATPs) where they exert their toxicity via inhibition of protein phosphatases 1 and 2A (Runnegar et al. 1991). Inhibition of protein phosphatases leads to excessive phosphorylation of structural filaments, with subsequent cyto-skeletal degradation and breakdown of hepatic ultra-structure (Eriksson et al. 1990; Sahin et al. 1995). Contraction of hepatocytes and sinusoidal capillaries causes blood to pool in the liver tissue, ultimately resulting in local tissue damage, organ failure and haemorrhagic shock (Sahin et al. 1995). Studies documented by Nishiwaki-Matsushima et al. (1992) produced evidence of liver tumour promotion by MC-LR. Moreover, MC-LR has been characterised as a Group 2B carcinogen by the International Agency for Research on Cancer (IARC) i.e. it is possibly carcinogenic to humans (IARC 2010). Cylindrospermopsin can also inhibit protein synthesis and is considered a potential carcinogen due to its cytotoxicity and genotoxicity (Moreira et al. 2013). Cylindrospermop$\sin (\mathrm{CYN})$ primarily inhibits protein $\mathrm{P} 450$ and glutathione synthesis, which can lead to cell death in organs such as the lungs, intestines, liver and kidneys, with this occurring through irreversible inhibition of protein synthesis (Bernard et al. 2003).

Increased eutrophication in Lake Victoria over the last four decades has resulted in the elevation of toxin producing cyanobacteria in all seasons of the year (Sekadende et al. 2005; (Ngupula et al. 2011; Mchau et al. 2019b). This increase has been related to the rising levels of nutrients, mainly phosphorus and nitrogen in the lake (Mbonde et al. 2004; Mchau et al. 2019b). Toxin producing cyanobacteria such as Microcystis and Anabaena, which produce MC and other toxins, have been identified and documented in all countries surrounded by Lake Victoria in East Africa. These countries include Tanzania, Kenya and Uganda (Sekadende et al. 2005; Okello et al. 2010; Sitoki et al. 2012; Mchau et al. 2019a). Rising temperatures have been thought to be a contributing factor to the increase in algal blooms globally. The continent of Africa is warming faster than the rest of the world, with one consequence of this being the increase in harmful algal blooms (HABs) and consequently cyanotoxins in freshwater bodies therein (Liu et al. 2011). This emphasizes the importance of strengthening water safety surveillance of cyanobacterial blooms, especially through monitoring the concentration of existing and emerging cyanotoxins.

The objective of this study focused on identification and quantification of cyanotoxins namely MCs (-LA, -LF, -LR, -LY, -LW, -RR, -YR, -WR, desmethylated (dm) MC-RR and desmethylated (dm) MC-LR), anatoxin-a (ATX-A), NOD and CYN in the freshwaters of the Ukerewe district and along the shores of Lake Victoria. Information obtained will add knowledge and understanding on the existence of multiple toxins in freshwater systems and the risk to the human population due to possible repeated long-term exposure.

\section{Materials and Methods}

\section{Study Site}

This study was conducted at the Ukerewe district with water collected from 23 different sites including the lakeshore, wells and treated pipe water as indicated in Table 1. Ukerewe District comprises 27 islands in Lake Victoria, Northern Tanzania between latitudes $10^{\circ} 45^{\prime}$ and $20^{\circ} 15^{\prime} \mathrm{S}$ and longitudes $320^{\circ} 45^{\prime}$ and $330^{\circ} 45^{\prime} \mathrm{E}$. Lake Victoria is the world's second largest freshwater body measured by surface area of $68,800 \mathrm{~km}^{2}$, and the largest in the developing world.

\section{Water Sample Collection}

A total of 138 water samples with a volume of one-litre (1 $\mathrm{Lt})$ each were collected based on three main water source categories, namely; lakeshore water (54), well water (66) and treated piped (18) water from 23 randomly selected field sites as shows on (Table 1). Additionally, samples were collected in 3 weeks consecutively. Sample collection was

Table 1 Water sample collection sites

\begin{tabular}{|c|c|c|}
\hline Lakeshore & Wells & Treated pipe water \\
\hline 1. Bugolora & 1. Busiri & $\begin{array}{l}\text { 1. Household } 1 \text { (pipe } \\
\text { water) }\end{array}$ \\
\hline 2. Chabilungo & 2. Buhima & $\begin{array}{l}\text { 2. Household } 2 \text { (pipe } \\
\text { water) }\end{array}$ \\
\hline 3. Galu beach & 3. Kakerege A & $\begin{array}{l}\text { 3. Treatment centre }(\mathrm{TC}) \text { - } \\
\text { treated }\end{array}$ \\
\hline 4. Water street agency & 4. Kakerege B & \\
\hline 5. Muhula lake & 5. Kasalu A & \\
\hline 6. Nanumi & 6. Kasalu B & \\
\hline $\begin{array}{l}\text { 7. Treatment centre } \\
\text { (TC)-untreated }\end{array}$ & 7. Muhula well & \\
\hline 8. Namagubo female & 8. Nakatunguru & \\
\hline \multirow[t]{3}{*}{ 9. Managubo male } & 9. Kenonzo & \\
\hline & 10. Namagondo & \\
\hline & 11. Pius Msekwa & \\
\hline
\end{tabular}


divided in two phases; Phase I sample collection was carried out during the dry season in the month of February $2018(n=69)$ and phase II sample collection during the rainy season in December $2018(n=69)$. The samples were collected and preserved as per the standard methods for examination of water (APHA 2012). Samples were stored in cool boxes and transported to Nelson Mandela Africa Institute of Science and Technology in Arusha (NM-AIST) where they were stored at $-20{ }^{\circ} \mathrm{C}$ prior to being shipped to Queen's University Belfast (QUB) for further analysis.

\section{Materials}

Standards for MCs (-LA, -LF, -LR, -LY, -LW, -RR, -YR, -WR, dm MC-RR and dm MC-LR) and NOD were purchased from Enzo Life Sciences (UK). Anatoxin-a (ATX-A) was purchased from the National Research Council, Canada, and CYN was obtained from N'Tox, France. Water was supplied from an in-house $18 \mathrm{M} \Omega$ Millipore water system, Millipore Ltd. (Hertfordshire, UK). Methanol, acetonitrile and formic acid were purchased from Sigma Aldrich (Dorset, UK).

\section{Analytical Standard Preparation}

ATX-A was provided reconstituted at a concentration of $4.96 \mu \mathrm{g} / \mathrm{mL}$, whereas the other toxins were in powder form $(100 \mu \mathrm{g})$. CYN was reconstituted in water and MC and NOD standards were reconstituted in pure methanol $(100 \mu \mathrm{L})$ to give stock standards of $1 \mathrm{mg} / \mathrm{mL}$. Working standards of $10 \mu \mathrm{g} / \mathrm{mL}$ were further prepared by diluting the stock standards of $1 \mathrm{mg} / \mathrm{mL} \mathrm{1:100} \mathrm{(v/v)} \mathrm{with} 80 \%$ aqueous methanol (v/v) and water for CYN. The multi-toxin stock standard containing all 13 standards was prepared at a concentration of $500 \mathrm{ng} / \mathrm{mL}$ by dilution of the $10 \mu \mathrm{g} / \mathrm{mL}$ working standards $1: 20(\mathrm{v} / \mathrm{v})$ and in the case of ATX-A by 1:9.92 (v/v) with $80 \%$ aqueous methanol (v/v).

\section{Extraction of Cyanotoxins}

The samples were not filtered to make sure all total toxins are detected (both intra- and extracellular levels) as depending on what phase certain cyanobacterial species present were in, some may have been extracellular and would therefore be lost by filtration. This is especially true of cylindrospermopsin, with approximately 70-98\% of cylindrospermopsin in toxic blooms of C. raciborskii reported as being extracellular (Kinnear 2010).

Extraction of cyanotoxins from the water samples collected was performed as outlined in (Greer et al. 2016) with some minor modifications as follows. After lyophilisation of a $100 \mathrm{~mL}$ aliquot, samples were extracted by resuspension in $5 \mathrm{~mL}$ of $75 \%$ aqueous methanol $(\mathrm{v} / \mathrm{v})$, vortex mixed briefly, then transferred to a $15 \mathrm{~mL}$ falcon tube, and vortex mixed for a further $30 \mathrm{~min}$ at room temperature, before centrifugation at $4500 \mathrm{rpm}$ for $15 \mathrm{~min}$. The supernatant was collected and evaporated to dryness under a gentle stream of nitrogen using a turbovap at $50{ }^{\circ} \mathrm{C}$. Samples were then reconstituted in $200 \mu \mathrm{L}$ of $80 \%$ aqueous methanol (v/v) and transferred to a micro vial for analysis.

Quantification of any toxins detected was achieved through the preparation of a seven-point matrix matched calibration curve in the range $5-1000 \mathrm{ng} / \mathrm{mL}$ and was prepared using blank water samples of $100 \mathrm{~mL}$. The concentrations of each calibrant were achieved by spiking with a multitoxin standard (MTS) at either 50 or $500 \mathrm{ng} / \mathrm{mL}$. Extraction efficiency was calculated by spiking blank matrix before and after with $50 \mu \mathrm{L}$ of the MTS at a concentration of $500 \mathrm{ng} /$ $\mathrm{mL}$, equating to a toxin level of $125 \mathrm{ng} / \mathrm{mL}$.

\section{Analysis of Cyanotoxins in TQ-MS}

Analysis of the 13 toxins was performed using a Xevo TQ-MS (triple quadrupole MS/MS) Mass Spectrometer (Waters, Manchester, UK). The system was operated in electrospray positive mode (ESI+) with the capillary voltage set at $1 \mathrm{kV}$, source and desolvation temperatures at $150{ }^{\circ} \mathrm{C}$ and $400{ }^{\circ} \mathrm{C}$, respectively, and desolvation gas flow at $700 \mathrm{~L} / \mathrm{h}$, optimised to give the best sensitivity across all analytes. Detection and quantification were achieved using targeted analysis via Multiple Reaction Monitoring (MRM) involving fragmentation of specific precursor ions (parent) using argon as the collision gas, to at least two product ions (daughters), with the cone voltages and collision energies for each analyte optimised manually as shows in (Table 2). Separation was achieved using a CORTECS UPLC T3 column, $100 \mathrm{~mm} \times 2.1 \mathrm{~mm}$ i.d., $1.6 \mu \mathrm{m}$ particle size, $120 \AA$ pore size (Waters, UK) with the column maintained at $45^{\circ} \mathrm{C}$. The mobile phases A and B consisted of water containing $0.1 \%$ formic acid (v/v) and acetonitrile, respectively. The flow rate was set at $0.45 \mathrm{~mL} / \mathrm{min}$ with the acetonitrile held at $2 \%$ for $1 \mathrm{~min}$, followed by an increase to $70 \%$ over $9 \mathrm{~min}$, washed for $1 \mathrm{~min}$ at $90 \%$ before returning to $2 \%$ for a $1 \mathrm{~min}$ re-equilibration before the next injection. The injection volume was set at $2 \mu \mathrm{L}$.

\section{Results and Discussion}

A total of 138 water samples were collected during Phase I and Phase II; 54 (39\%) from the lakeshore, 66 (48\%) from wells and 18 (13\%) from treated piped water. Results revealed that cyanotoxins were detected in eight out of nine selected sites (89\%) from the lakeshore waters. Several toxins such as, CYN, MCs, (-RR, -LR and -YR) and NOD were 
Table 2 Optimised MRM/SRM transitions for the 13 freshwater cyanotoxins
Table 3 Summary of samples showing mean concentration of toxins detection from different collection sites in phase I (dry seasons)

\begin{tabular}{lllllll}
\hline Analyte & Precursor ion & Cone $(V)$ & $\begin{array}{l}\text { Base frag- } \\
\text { ment ion }(Q)\end{array}$ & $\begin{array}{l}\text { Collision } \\
\text { Energy }(\mathrm{eV})\end{array}$ & $\begin{array}{l}\text { Qualifier } \\
\text { fragment }(q)\end{array}$ & $\begin{array}{l}\text { Collision } \\
\text { Energy } \\
(\mathrm{eV})\end{array}$ \\
\hline ATX-A* & 166.10 & 25 & 149.0 & 15 & 131.05 & 15 \\
CYN & 416.20 & 35 & 194.1 & 40 & 336.2 & 20 \\
dmMC-RR & 512.95 & 35 & 135.2 & 40 & 107.2 & 50 \\
MC-RR & 519.95 & 35 & 135.0 & 30 & 127.1 & 40 \\
NOD & 825.50 & 65 & 135.1 & 65 & 70.0 & 75 \\
MC-LA & 910.50 & 32 & 135.1 & 65 & 213.1 & 60 \\
dmMC-LR & 981.55 & 50 & 135.1 & 70 & 107.1 & 70 \\
MC-LF & 986.50 & 35 & 135.1 & 70 & 213.1 & 55 \\
MC-LR & 995.60 & 55 & 135.0 & 75 & 107.05 & 80 \\
MC-LY & 1002.5 & 35 & 135.15 & 70 & 163.1 & 60 \\
MC-LW & 1025.6 & 25 & 135.1 & 65 & 107.1 & 65 \\
MC-YR & 1045.5 & 60 & 135.2 & 70 & 107.1 & 75 \\
MC-WR & 1068.55 & 60 & 135.1 & 75 & 107.1 & 75 \\
\hline
\end{tabular}

Optimised MRM/SRM transitions for the 13 freshwater toxins (cyanotoxins) including; quantifier ion $(Q)$ and qualifying ion $(q)$

*ATX-A has a second qualifier fragment $(q 1)$ which is the diagnostic ion and is used to prevent misidentification; $q 1=166.1>42.95$ with a collision energy of $20 \mathrm{eV}$ (not shown in table)

\begin{tabular}{llllll}
\hline Sampling location & CYN $(\mu \mathrm{g} / \mathrm{L})$ & MC-RR $(\mu \mathrm{g} / \mathrm{L})$ & MC-LR $(\mu \mathrm{g} / \mathrm{L})$ & MC-YR $(\mu \mathrm{g} / \mathrm{L})$ & $\mathrm{NOD}(\mu \mathrm{g} / \mathrm{L})$ \\
\hline Bugorola & 0.01 & 0.0067 & & & 0.010 \\
Chabilugo & 0.007 & & & \\
Galu beach & 0.0069 & 0.0035 & & 0.0128 & \\
Water agency street & 0.0057 & 0.0028 & & 0.0118 \\
Muhula lake & 0.0062 & 0.0028 & 0.0118 & \\
Nanumi & & & & 0.013 & \\
TC-untreated & 0.004 & & & 0.0118 \\
Namagubo female & 0.005 & 0.0029 & & & \\
Namagubo male & 0.0045 & & 0.0102 & \\
\hline
\end{tabular}

identified in phase I (Table 3). In phase II, cyanotoxins were identified in four (44\%) sites only, with only CYN and MCs (-RR and -LY) detected (Table 4). No cyanotoxins were detected in wells and treated pipe water samples.

CYN was detected in eight $(89 \%)$ of lakeshore collection sites with concentrations ranging from 0.01 to $0.004 \mu \mathrm{g} / \mathrm{L}$ (Table 3). NOD was detected in one site with a concentration of $0.010 \mu \mathrm{g} / \mathrm{L}$ (Table 3 ). The study shows the presence of MC congeners, -RR, -LR and -YR with concentrations ranging from 0.003 to $0.009 \mu \mathrm{g} / \mathrm{L}$ for MC-RR, 0.010-0.012 $\mu \mathrm{g} / \mathrm{L}$ for MC-LR and $0.012-0.013 \mu \mathrm{g} / \mathrm{L}$ for MC-YR in phase I. Furthermore, in phase I, MC-RR was detected in $5(55.6 \%)$ of the lakeshore samples collection sites (Fig. 2) whilst MC-LR and MC-YR were detected in 2 (22.2\%) and 4 $(44.4 \%)$ collection sites, respectively. No cyanotoxins were detected in any of the water samples collected from the wells or from the treated piped water in phase I.
Table 4 Summary of samples showing toxins profile above detection levels from different collection sites in phase II (rainy seasons)

\begin{tabular}{llll}
\hline Sampling site & CYN $(\mu \mathrm{g} / \mathrm{L})$ & MC-RR $(\mu \mathrm{g} / \mathrm{L})$ & MC-LR $(\mu \mathrm{g} / \mathrm{L})$ \\
\hline Bugorola & 0.0122 & 0.004 & \\
Chabilungo & 0.004 & & 0.01 \\
$\begin{array}{l}\text { Water agency street } \\
\text { Muhula lake }\end{array}$ & 0.0078 & 0.0038 & \\
\hline
\end{tabular}

Phase II results indicated that CYN was detected in water samples from the lake with concentrations ranging from 0004 to $0.0122 \mu \mathrm{g} / \mathrm{L}$ in three $(44 \%)$ collection sites. MC-LR was detected in one site with a concentration of $0.01 \mu \mathrm{g} / \mathrm{L}$ whilst MC-RR was present in two sites with concentrations of 0.004 and $0.0038 \mu \mathrm{g} / \mathrm{L}$ (Table 4 ). No cyanotoxins were detected in water samples from the wells and treated pipe water in phase II. 
The combined toxin load found in phase I was substantially higher when compared to phase II with the exception of CYN where there was only a slight increase in maximum concentrations of $0.011 \mu \mathrm{g} / \mathrm{L}$ in phase I to $0.012 \mu \mathrm{g} / \mathrm{L}$ in phase II. Microcystin congeners -RR, -LR and -YR, CYN and NOD were all detected in phase I, whereas only microcystin congeners -RR, -LR as well as CYN were detected in phase II.

CYN was the most abundant cyanotoxin, observed in $89 \%$ of all the collection sites, and in week 2 it was detected in all eight sites whereas in week 3 it was detected in six sites (Fig. 1). Samples from the lake indicated the presence MC-RR in $5(55.6 \%)$ of the collection sites, making it the second most dominant toxin in terms of the number of times it was detected at the collection sites (Fig. 2).

Water samples collected from the catchment area of the treatment plant (Treatment Centre (TC)-Untreated) in phase I were contaminated with $\mathrm{CYN}$ and MC-YR at concentrations of $0.005 \mu \mathrm{g} / \mathrm{L}$ and $0.013 \mu \mathrm{g} / \mathrm{L}$, respectively, with no toxins detected after treatment. In phase II, no toxins were detected either before or after treatment.

Amongst 23 sampling areas, only lake sites were presented with various type of toxins as shown in (Table 3,4). Whereby, the number of toxins identified and their concentration can be used to determine the exposure risk level. With this in mind, there were four of the nine lake collection sites considered extremely high-risk, (44.4\%), whilst three

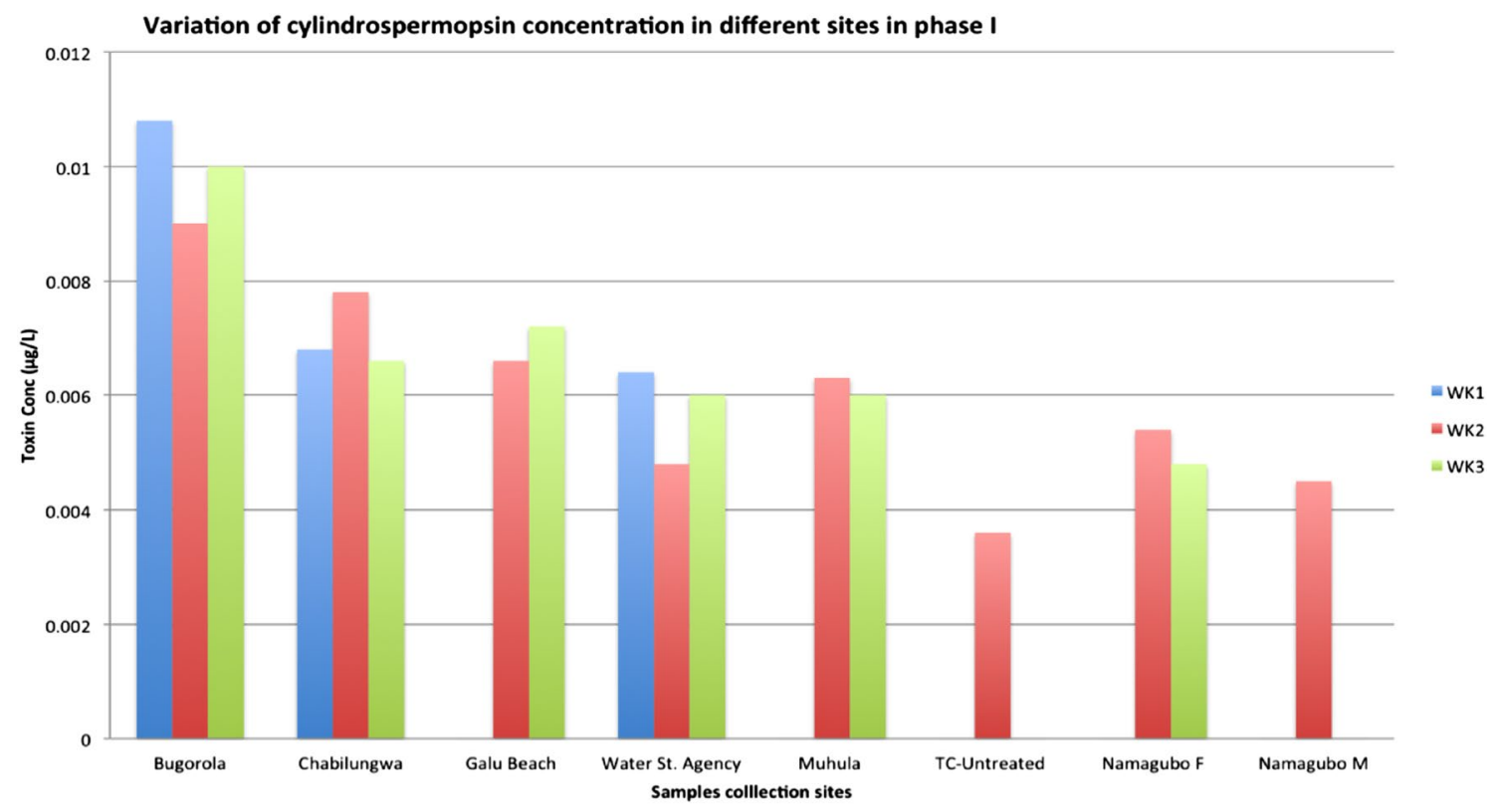

Fig. 1 Variation of cylindrospermopsin concentrations in phase I samples over a period of 3 weeks in lake collection sites

Concentration of MC-RR in defferent sites in phase I

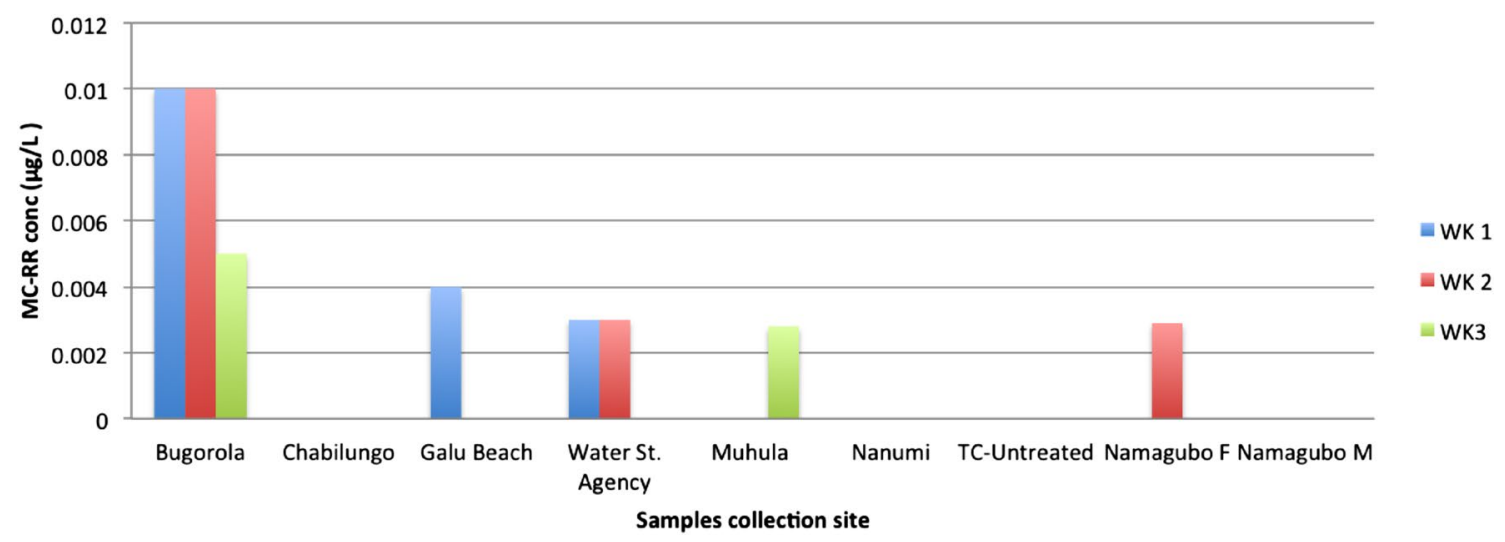

Fig. 2 Variation of MC-RR concentrations in samples collected over a period of 3 weeks in phase I (dry seasons) in lake collection sites 
of the nine lake collection sites were considered high-risk (33.3\%). This is indicated by the intensity of the colour on the map, which corresponds to the level of risk, shown in Fig. 5.

\section{Discussion}

This study presents new evidence concerning the detection of the toxins CYN and NOD in Lake Victoria (Figs. 3, 4) respectively. In this study, we analysed thirteen cyanobacterial toxins and of these, CYN was the most abundantly detected in 8 out of 9 and 3 out of 9 of the lakeshore samples collection sites in phase I (dry season) and phase II (wet season) respectively (Tables 3,4). Originally it was thought that this toxin was predominantly found in toxic blooms in subtropical, tropical or arid zone freshwater bodies, however, the hepatotoxin has been increasingly identified in temperate European waters such as Germany and France (Fastner et al. 2003) and in Ireland (Greer et al. 2016). The hepatotoxins have been reported to be potent protein phosphatase 1 and 2A inhibitors which has been shown to have long-term cumulative toxic effect for potential tumour formation (Rastogi et al. 2015). Therefore, the toxicity and carcinogenic potential of NOD in humans has not been well characterised and therefore, the findings of this investigation emphasise the need for further work in the detection and effects of NOD on human health.

This study detected microcystins in 7 out 9 of the lakeshore sample collection sites (Table 3), with the main variants identified being MC-LR, MC-RR and MC-YR (Tables 3, 4), slightly higher than the levels reported
Fig. 3 Chromatograms of the cyanotoxin CYN; the top chromatogram shows the CYN standard, with the bottom chromatogram indicating a sample positive for CYN (TZA_WO2A is water sample of week 2 from Bugolora site)

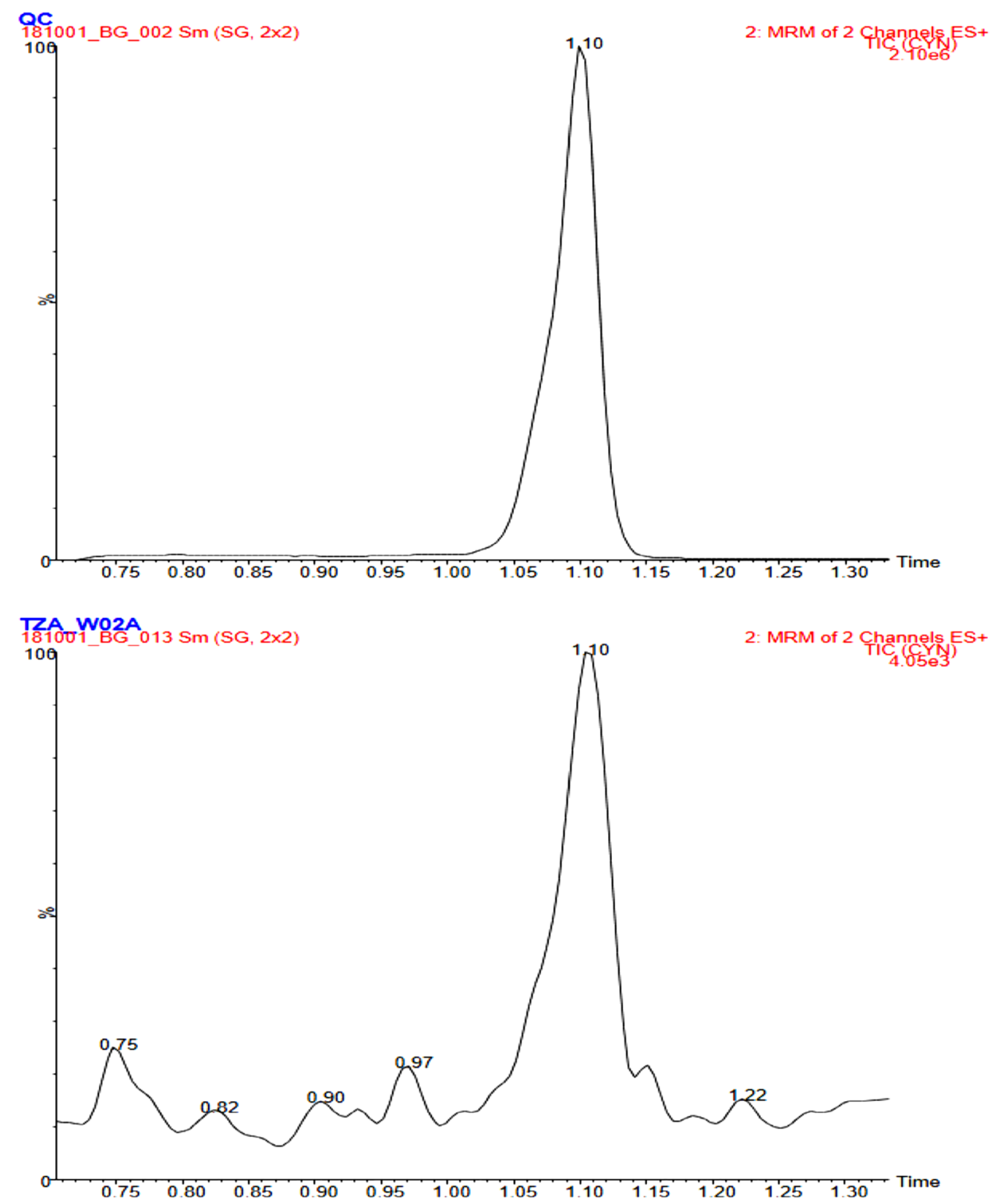


Fig. 4 Chromatograms of the cyanotoxin NOD; the top chromatogram shows the NOD standard, with the bottom chromatogram indicating a sample positive for NOD (TZA W03A is a water sample of week 3 from Bugolora site)$$
\text { QC }
$$

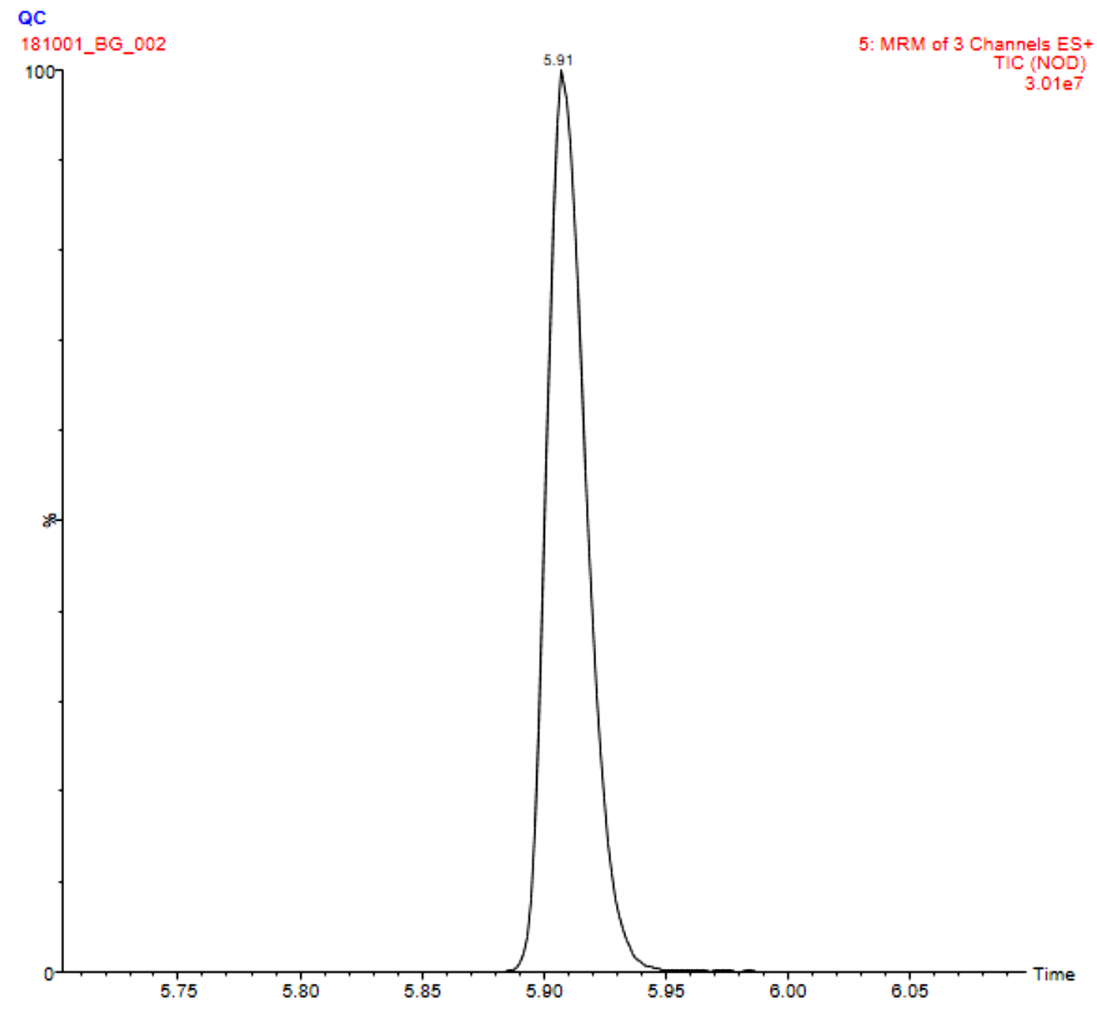

TZA_W03A

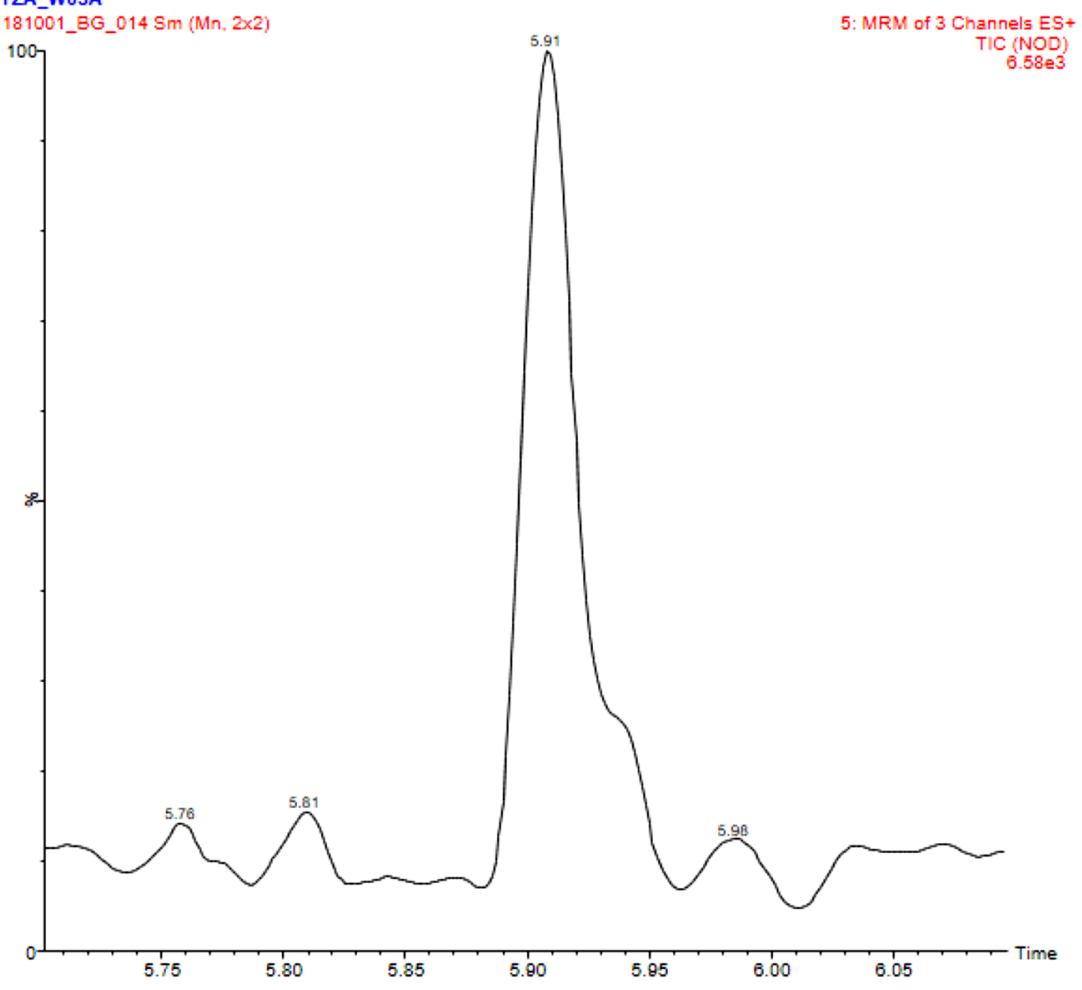

in cyanotoxin surveillance across several European countries by Greer et al. (2016). The occurrence of MC-LR, MC-RR and MC-YR toxins has been associated with the presence of dominant cyanobacteria species Anabaena and Microcystis that can potentially produce MCs (Okello et al. 2010). This was also reported in a study conducted in Lake Victoria in the Mwanza and Musoma regions in Tanzania by Mbonde et al. (2015). Furthermore, the occurrence of these toxigenic cyanobacteria has been documented in studies carried out in Kenya and Uganda on the Lake Victoria shores (Okello et al. 
2010; Sitoki et al. 2012). It has been shown that MC-RR and MC-LR are the most occurring types of MC toxins in freshwaters (Mbonde et al. 2015; Okello et al. 2010), which was the case in this study. However, the variation of MC detection and concentration in different location of the lakeshores may be due to the life cycle of different cyanobacteria species as well as bloom concentration. MC toxins concentration have been shown to exhibit seasonal variation, whereby it has been observed to be higher during the dry season compared to the rainy season. In this study, we observed the concentrations of microcystin congeners -RR, -LR and -YR ranging from 0.003 to $0.013 \mu \mathrm{g} / \mathrm{L}$ in phase I, considered as the dry season, whilst in phase II (rainy season), only MC-RR and MC-LR were observed with concentrations ranging from 0.004 to $0.010 \mu \mathrm{g} / \mathrm{L}$.

The concentrations of cyanotoxins detected in this study were below the WHO provisional acceptable limit of $1.0 \mu \mathrm{g} / \mathrm{L}$ for MC-LR in drinking water (WHO 2008). In this study, however, we found far lower concentrations of MCs in Lake Victoria waters compared to studies conducted in other locations along Lake Victoria (Sekadende et al. 2005; Okello et al. 2010; Mbonde et al. 2015). This could be due to seasonal variation, influenced by the nutrients load of the water body, as well as the levels of eutrophication during different sampling periods and selected sites. This seasonal variation of cyanotoxins has been observed in studies conducted elsewhere in Uganda along the Lake Victoria shores (Okello et al. 2010). Studies conducted by Mbonde et al. (2015) in Lake Victoria showed the MC-LR concentrations ranged from 0.4 to $13 \mu \mathrm{g} / \mathrm{L}$, above the WHO recommended limits, indicating the possibility of extreme high risk of health effects to the population living along the Lakeshores. On other hand, Mchau et al. (2019a) reported a number of health effects due to the extreme exposure to cyanobacteria bloom of Microcystis aeruginosa and Anabaena spp in the same district, which are capable of producing the types of toxins reported in this study. Those health effects included throat, eye and skin irritation and Gastrointestinal Illness (GI) such as vomiting, stomach upset and diarrhoea amongst lake water users as compared to pipe and well water. The cyanotoxins detected included the cyclic peptides MC and NOD, as well as tricyclic alkaloid CYN, which are all considered hepatotoxic. The International Agency for Research on Cancer (IARC) characterized MC-LR as a Group 2B carcinogen, with strong evidence supporting the fact that it has the capacity to exhibit tumour promotion (IARC 2010), whilst CYN is also considered as possibly carcinogenic (Moreira et al. 2013) The lack of a well-established surveillance system to detect and record illnesses (acute/chronic) related to exposure to cyanotoxins limits the understanding on the possible health effect of Ukerewe population exposed to observed multiple toxins in the Lake.

The existence of multiple toxins in Lake Victoria freshwaters are compounded with the possibility of multiple exposures to the human population from recreational activities, fishing and the consumption of both contaminated aquatic organisms and water (Rastogi et al. 2015). Existence of multiple toxins in the Lake increases the

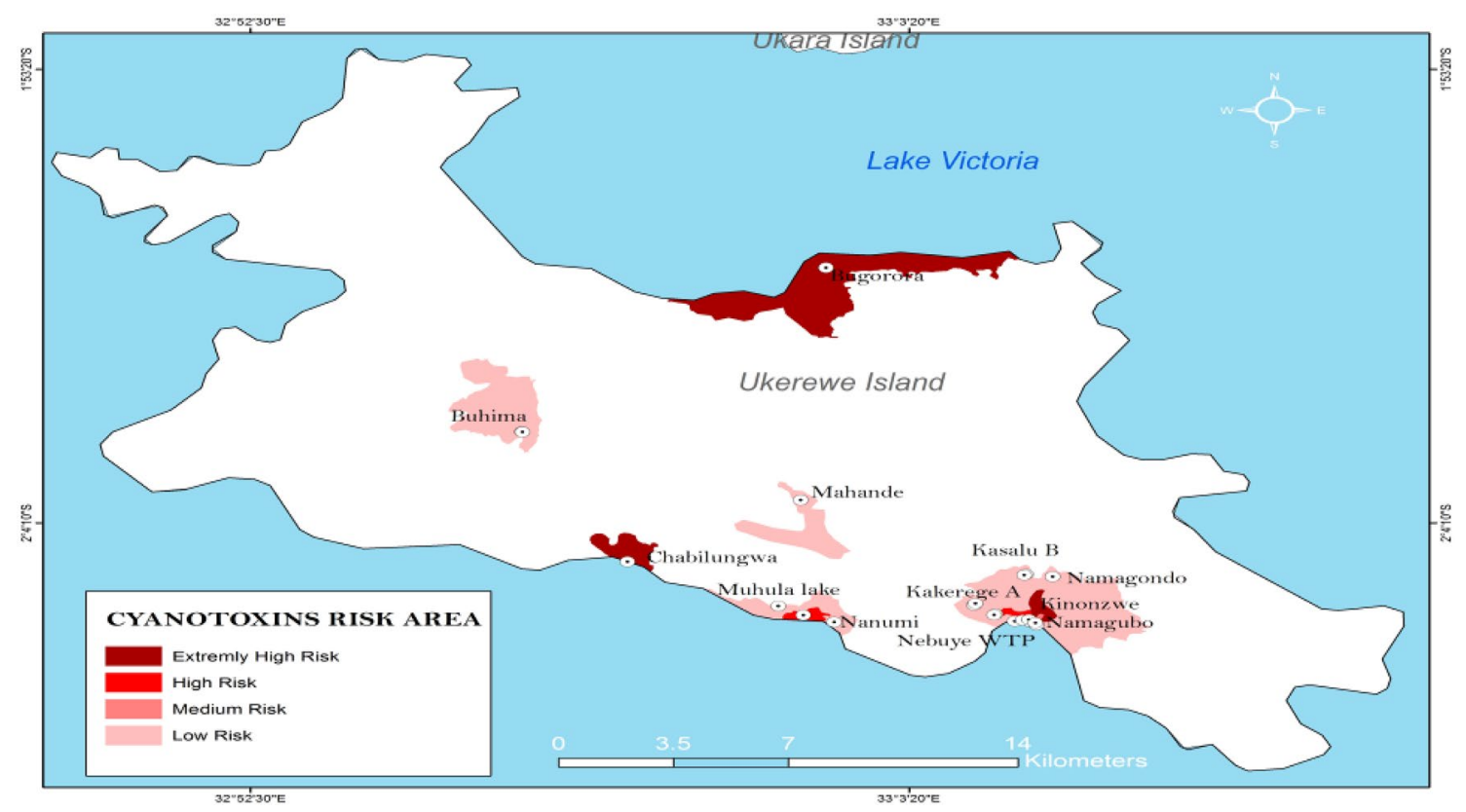

Fig. 5 Cyanotoxins risk areas on Ukerewe Island, Lake Victoria graded from extremely high risk to low risk based on cyanotoxin levels identified in those sampling sites 
potential of enhanced toxicity due to synergistic effects, as well as an increased possibility of bioaccumulation due to the presence of several toxins in some water bodies, whereby the concentration of toxins in the tissues of aquatic organisms exceeds those of the surrounding water body. Humans being at the top of food chain can therefore be the recipients of these freshwater toxins that may have accumulated in fish, as well as from agricultural products along the lake, meat from livestock that consume the lake water as well as the consumption of the lake water itself, with all routes increasing the risk of exposure. Since there is limited safe water supply on the island, with only $18 \%$ of the population receiving treated pipe water, more of the population are at risk of toxin exposure. This is especially true as the majority of people live along the Lakeshores where the risk is deemed higher (Fig. 5), with the results showing that eight out of nine $(89 \%)$ locations indicate the presence of multiple toxins (Tables 3,4). The risk of increased cyanotoxin production in Africa is expected to be higher due to the increase in temperature (Lui et al. 2011). In the developing countries, little has been done to develop strategies for cyanotoxin prevention and control in food and in water supplies. This raises concerns that multiple toxins exist and which have been detected, therefore increasing the risk to human health (Rastogi et al. 2015).

MCs are reported to have cumulative effects by Fitzgeorge et al. (1994), which may be explained by the irreversible covalent binding of the toxin to the protein phosphatases and subsequent substantial damage to the cell structure (Falconer 1993; Greer et al. 2018). The cumulative effects of toxins may cause sub-acute liver cell injury, which is likely to go unnoticed up to a level closer to acute severe toxicity. In most cases, the lack of apparent symptoms at moderate exposure to these toxins is likely to continue, as individuals are unaware of the repeated exposure. The repetitive and multiple toxin exposures, even at relatively low doses may cause cumulative liver damage, which in the long term may lead to chronic liver diseases. (Chorus et al. 2000; Chen et al. 2009).

All 18 water samples from treated piped water in household and treatment centre (Treatment Centre (TC)-Treated) sites in Ukerewe district did not show the presence of cyanotoxins, whereas in the catchment (Lake Victoria) area of this water before treatment, both CYN and MC-RR were detected. Water treatment at the district involves the application of aluminium sulphate $(5 \mathrm{mg} / \mathrm{L})$ followed by flocculation then chlorination $(2 \mathrm{mg} / \mathrm{L})$. Chemical water treatment approaches have proven to be the most effective means of treating cyanobacterial blooms and cyanotoxins (Bogialli et al. 2012). Lelkova et al. (2008) observed similar findings where aluminium sulphate was found to be effective in the treatment algae and cyanobacteria. Based on these finding it is therefore important for the Tanzanian water authority to acknowledge the occurrence/existence of cyanotoxins and its potential health risk to the population that consume water from Lake Victoria fresh waters and mitigate measures to control cyanobacteria blooms. There is the evidence that water is safe for human consumption when it undergoes treatment before consumption since there were no toxins detected after treatment.

\section{Conclusion}

This study brings the novelty and awareness of the cooccurrence of cyanotoxins in the freshwaters of Lake Victoria, which is regularly used by the general population. The toxins detected might present a threat to human health if water is used without treatment, with the finding of multiple toxins in Lake Victoria also posing a greater risk to human health when the water is consumed without treatment. Multiple and repeated exposure of cyanotoxins may enhance the levels of toxicity as well as the possibility of synergistic effects. There is a need for the development of structured surveillance systems for the detection of toxins in freshwaters used for human consumption and recreational purposes. On the other hand, health systems must be well established to be able to detect and record illness related to cyanotoxins.

Long-term studies should be conducted to enhance our understanding on the effects attributed to the increase of cyanotoxins and emerging toxins such as CYN and NOD. Research gaps must be bridged to address the possible effect of bioaccumulation in a long-term exposure to human and other aquatic organisms.

Acknowledgements This research was supported by the Science Foundation Ireland-Department for Employment and Learning (SFI-DEL) Investigators Programme Partnership (Project 14/IA/2646)

Open Access This article is licensed under a Creative Commons Attribution 4.0 International License, which permits use, sharing, adaptation, distribution and reproduction in any medium or format, as long as you give appropriate credit to the original author(s) and the source, provide a link to the Creative Commons licence, and indicate if changes were made. The images or other third party material in this article are included in the article's Creative Commons licence, unless indicated otherwise in a credit line to the material. If material is not included in the article's Creative Commons licence and your intended use is not permitted by statutory regulation or exceeds the permitted use, you will need to obtain permission directly from the copyright holder. To view a copy of this licence, visit http://creativecommons.org/licenses/by/4.0/.

\section{References}

APHA (2012) APHA 2012 standard methods for the examination of water and wastewater 2012, 22nd edn. American Public Health 
Association (APHA)/American Water Works Association (AWWA)/Water Environment Federation (WEF), Washington, DC

Bernard C, Harvey M, Briand JF, Biré R, Krys S, Fontaine JJ (2003) Toxicological comparison of diverse Cylindrospermopsis raciborskii strains: evidence of liver damage caused by a French $C$. raciborskii strain. Environ Toxicol 18(3):176-186

Bogialli S, di Gregorio F, Lucentini L, Ferretti E, Ottaviani M, Ungaro N, Abis PP, de Grazia M (2012) Management of a toxic cyanobacterium bloom (Planktothrix rubescens) affecting an Italian drinking water basin: a case study. Environ Sci Technol 47(1):574-583

Buratti FM, Manganelli M, Vichi S, Stefanelli M, Scardala S, Testai E, Funari E (2017) Cyanotoxins: producing organisms, occurrence, toxicity, mechanism of action and human health toxicological risk evaluation. Arch Toxicol 91(3):1049-1130

Carmichael WW (1992) Cyanobacteria secondary metabolites-the cyanotoxins. J Appl Microbiol 72(6):445-459

Carmichael WW, Azevedo SM, An JS, Molica RJ, Jochimsen EM, Lau S, Rinehart KL, Shaw GR, Eaglesham GK (2001) Human fatalities from cyanobacteria: chemical and biological evidence for cyanotoxins. Environ Health Perspect 109(7):663-668

Chen J, Xie P, Li L, Xu J (2009) First identification of the hepatotoxic microcystins in the serum of a chronically exposed human population together with indication of hepatocellular damage. Toxicol Sci 108(1):81-89

Chorus I, Falconer IR, Salas HJ, Bartram J (2000) Health risks caused by freshwater cyanobacteria in recreational waters. J Toxicol Environ Health Part B Crit Rev 3(4):323-347

Eriksson JE, Toivola D, Meriluoto JAO, Karaki H, Han YG, Hartshorne D (1990) Hepatocyte deformation induced by cyanobacterial toxins reflects inhibition of protein phosphatases. Biochem Biophys Res Commun 173(3):1347-1353

Falconer IR (1993) Mechanism of toxicity of cyclic peptide toxins from blue-green algae, algal toxins in seafood and drinking water, chapter 11, 177-186. Academic Press, Cambridge

Fastner J, Heinze R, Humpage AR, Mischke U, Eaglesham GK, Chorus I (2003) Cylindrospermopsin occurrence in two German lakes and preliminary assessment of toxicity and toxin production of Cylindrospermopsis raciborskii (Cyanobacteria) isolates. Toxicon 42(3):313-321

Funari E, Testai E (2008) Human health Risk assessment related to cyanotoxins exposure. Crit Rev Toxicol 38(2):97-125

Greer B, McNamee SE, Boots B, Cimarelli L, Guillebault D, Helmi K, Marcheggiani S, Panaiotov S, Breitenbach U, Akçaalan R et al (2016) A validated UPLC-MS/MS method for the surveillance of ten aquatic biotoxins in European brackish and freshwater systems. Harmful Algae 55:31-40

Greer B, Meneely JP, Elliott CT (2018) Uptake and accumulation of microcystin-LR based on exposure through drinking water: an animal model assessing the human health risk. Sci Rep 8(1):4913

IARC (2010) IARC monographs on the evaluation of carcinogenic risks to humans. Ingested nitrate and nitrite, and cyanobacterial peptide toxins, vol 94. IARC Monographs on the Evaluation of Carcinogenic Risks to Humans/World Health Organization, International Agency for Research on Cancer, Lyon

Kibria G (2016) Blue-green algal toxins/cyanobacterial toxins (BGA), climate change and BGA impacts on water quality, fish kills, crops, seafood, wild animals and humans. 7p. https://doi. org/10.13140/RG.2.1.1306.9765/1

Kinnear S (2010) Cylindrospermopsin: a decade of progress on bioaccumulation research. Mar Drugs 8(3):542-564

Lelkova E, Rulik M, Hekera P, Dobias P, Dolejs P, Borovickova M, Poulickova A (2008) The influence of the coagulant PAX-18 on Planktothrix agardhii bloom in a shallow eutrophic fishpond. Fottea $8(2): 147-154$
Liu X, Lu X, Chen Y (2011) The effects of temperature and nutrient ratios on Microcystis blooms in Lake Taihu, China: an 11-year investigation. Harmful Algae 10(3):337-343

Mbonde ASE, Shayo S, Sekadende BC, Lyimo TJ (2004) Phytoplankton species diversity and abundance in the near shore waters of Tanzanian side of Lake Victoria. Tanzania J Sci 30(1):71-81

Mbonde AS, Sitoki L, Kurmayer R (2015) Phytoplankton composition and microcystin concentrations in open and closed bays of Lake Victoria, Tanzania. Aquat Ecosyst Health Manag 18(2):212-220

Mchau GJ, Makule E, Machunda R, Gong YY, Kimanya M (2019a) Harmful algal bloom and associated health risks among users of Lake Victoria freshwater: Ukerewe Island, Tanzania. J Water Health 17(5):826-836

Mchau GJ, Makule E, Machunda R, Gong YY, Kimanya M (2019b) Phycocyanin as a proxy for algal blooms in surface waters: case study of Ukerewe Island, Tanzania. Water Pract Technol

Moreira C, Azevedo J, Antunes A, Vasconcelos V (2013) Cylindrospermopsin: occurrence, methods of detection and toxicology. J Appl Microbiol 114(3):605-620

Ngupula GW, Mbonde ASE, Ezekiel CN (2011) Spatial and temporal patterns of phytoplankton abundance and composition in three ecological zones in the Tanzanian waters of Lake Victoria. Afr J Aquat Sci 36(2):197-206

Nishiwaki-Matsushima R, Ohta T, Nishiwaki S, Suganuma M, Kohyama K, Ishikawa T, Carmichael WW, Fujiki H (1992) Liver tumor promotion by the cyanobacterial cyclic peptide toxin microcystinLR. J Cancer Res Clin Oncol 118(6):420-424

Okello W, Ostermaier V, Portmann C, Gademann K, Kurmayer R (2010) Spatial isolation favours the divergence in microcystin net production by microcystis in Ugandan freshwater lakes. Water Res 44(9):2803-2814

Organization WH et al (2008) Guidelines for drinking-water quality: second addendum. Vol. 1, Recommendations. World Health Organization, Geneva

Pouria S, de Andrade A, Barbosa J, Cavalcanti RL, Barreto VTS, Ward CJ, Preiser W, Poon GK, Neild GH, Codd GA (1998) Fatal microcystin intoxication in haemodialysis unit in Caruaru, Brazil. The Lancet 352(9121):21-26

Rastogi RP, Madamwar D, Incharoensakdi A (2015) Bloom dynamics of cyanobacteria and their toxins: environmental health impacts and mitigation strategies. Front Microbiol 6:1254

Runnegar MTC, Gerdes RG, Falconer IR (1991) The uptake of the cyanobacterial hepatotoxin microcystin by isolated rat hepatocytes. Toxicon 29(1):43-51

Sahin A, Tencalla FG, Dietrich DR, Mez K, Naegeli H (1995) Enzymatic analysis of liver samples from rainbow trout for diagnosis of blue-green algae-induced toxicosis. Am J Vet Res 56(8):1110-1115

Sekadende BC, Lyimo TJ, Kurmayer R (2005) Microcystin production by cyanobacteria in the Mwanza Gulf (Lake Victoria, Tanzania). Hydrobiologia 543(1):299-304

Sitoki L, Kurmayer R, Rott E (2012) Spatial variation of phytoplankton composition, biovolume, and resulting microcystin concentrations in the Nyanza Gulf (Lake Victoria, Kenya). Hydrobiologia 691(1):109-122. https://doi.org/10.1007/s10750-012-1062-8

Publisher's Note Springer Nature remains neutral with regard to jurisdictional claims in published maps and institutional affiliations. 